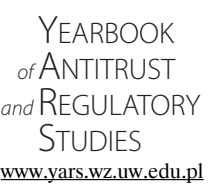

Peer-reviewed scientific periodical, focusing on legal and economic issues of antitrust and regulation. Creative Commons Attribution-No Derivative Works 3.0 Poland License.

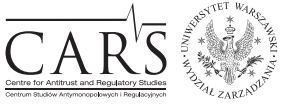

Centre for Antitrust and Regulatory Studies, University of Warsaw, Faculty of Management www.cars.wZ.uw.edu.pl

\title{
The French System of Antitrust Enforcement: A Sui Generis Monist Model
}

\author{
by \\ Andrea Pezza*
}

\section{CONTENTS}
I. Introduction
II. The proceeding before the French Competition Authority
III. The strengths and the weaknesses of the French system
IV. Conclusion

\begin{abstract}
The paper examines strengths and weakness of the French system of competition enforcement, with the aim of contributing to the discussion on the institutional design of systems of competition law enforcement. In this regard, special attention will be devoted to choosing to introduce a clear separation between investigative and adjudicative functions within the same institution: while this solution ensures compliance with the impartiality principle, it also implies a lack of coordination between the board and the investigative services, which could have negative consequences for the administrative activity of the institution.
\end{abstract}

\section{Résumé}

Larticle examine les forces et les faiblesses de l'Autorité de la concurrence française, dans le but de contribuer au débat sur la structure institutionnelle la plus appropriée pour les autorités de la concurrence. À cet égard, une attention particulière sera

* Andrea Pezza, LLM in European Legal Studies at College of Europe (Bruges). Currently Ph.D. Candidate in Economic Law at University of Naples Federico II - Department of Law. An earlier version of this contribution was presented at the First Gaetano Filangieri Conference on Freedom of Commerce 'Recent developments in EU Competition Law', held at the University of Naples 'Federico II' on 8-9 May 2018. Article received: 23 June 2018; accepted: 4 July 2018. 
accordée à l'introduction - dans le même Autorité - d'une séparation entre les services d'instruction et le Collège: une solution qui assure l'impartialité des choix pris par l'institution, mais qui détermine aussi une manque de coordination entre le Collège et le Services d'instruction qui peut avoir des effets négatifs sur l'activité administrative de l'institution.

Key words: competition law; France; impartiality; rights of defence; autorité de la concurrence

JEL: K21

\section{Introduction}

The institutional design of a system of competition law enforcement is an issue that - since the early 2000 - has often been the topic of debate. The present paper aims at contributing to the discussion examining the French competition system, as structured following the reform approved in 2008 by the President of the French Republic N. Sarkozy.

As it will be shown, the main peculiarity of the French system is the presence of measures aimed at ensuring the adoption of an impartial decision, as required - inter alia - also by Article 6 of the European Convention on Human Rights (hereinafter; ECHR). However, alongside this feature, the French system presents a great number of other characteristics that deserve attention and that will be scrutinized in order to assess their compliance with other requirements laid down in Article 6 ECHR.

Such analysis would make it possible to define the strengths and weaknesses of the system, and could provide some food for thought even for amending other systems of competition law enforcement.

\section{The proceeding before the French Competition Authority}

The current French system of competition enforcement was set up in 2008, when the Loi pour la Modernisation de l'Economie 1 instituted the Autorité de la Concurrence (hereinafter; ADC) and transferred to it relevant competences

\footnotetext{
${ }^{1}$ Law 2008-776 of 4 August 2008. See also the Ordonnance n. 2008-1161 of 13 November 2008 that amends the French Commercial Code. The law is part of an extensive programme of reform launched by the President of the French Republic N. Sarkozy for stimulating the economic growth of the country, elaborated on the basis of the works of the Commission pour
} 
which were, at that time, shared between the Conseil de la Concurrence and the Ministry of Economic Affairs² (Lasserre, 2008 pp. 2-4).

As it will be shown, the major characteristic of such a system is represented by the clear separation between investigative and adjudicative functions: in fact, although the ADC - like the greatest part of European competition enforcers ${ }^{3}$ - cumulates both of those functions (they are all 'monist models'), it has introduced strong provisions aimed at ensuring a functional separation between the investigative services and the Board.

The investigation is, in fact, carried out by the investigative services (Services d'Instruction $),{ }^{4}$ placed under the responsibility of the Rapporteur General, ${ }^{5}$ with no specific involvement of the Board. In particular, the Rapporteur General is in charge of designating the official responsible for the investigation (Rapporteur), supervising the proper conduct of the investigation, and ensuring the quality of the documents produced (Communication of the preliminary findings, Report of Inquiry and other documents). ${ }^{6}$ Furthermore - at the request of the Rapporteur or of a party - the Rapporteur General may also appoint an expert to carry out technical activities indicated by the parties, to be dealt with in adversarial proceedings. ${ }^{7}$

la liberation de la croissance, chaired by J. Attali, and available at the following link: http://www. ladocumentationfrancaise.fr/var/storage/rapports-publics/084000041.pdf.

2 Before the reform, competition policy was shared between the Conseil de la Concurrence and the Ministry of Economic affairs, with the latter responsible for merger control and for ensuring the compliance of undertakings with the Conseil's decisions.

3 With the exception of Austria, Denmark, Finland, Ireland, Sweden, which adopt a dualist model, characterized by the attribution of investigative and adjudicative functions to different institutions (generally the first one is attributed to the competition authority, while the second to a specialized Court).

4 The Services d'Instruction are composed if five sections, plus a person responsible for the leniency procedures: i) Competition (in charge of carrying out the investigations and making opinions); ii) Investigations (in charge of inspections and gathering of information); iii) Concentrations; iv) regulated professions; v) economic service.

5 The Rapporteur General - like the Deputy Rapporteur General - is appointed for a term of four years (renewable only once) and is chosen among the members of the Council of State, judges, category A officials or those who - having a diploma giving access to category A officials - have gained at least five years of experience in the field of competition law (see Code du Commerce, art. R-461-3).

${ }^{6}$ See Code du Commerce, art. R 461-3.

7 See Code du Commerce, art. L-463-8 and R463-16. It should be pointed out that respecting 'adversarial' proceeding does not mean that the parties should be present to all the technical operations put in place by the expert, being sufficient that they are constantly informed and in the position of expressing their opinions (see Cons. Conc., Decision 04-D-79). 
During the first stage of the investigation - devoted to the collection of evidence - parties do not fully enjoy their rights of defence, given that they cannot access the file ${ }^{8}$ nor ask to be heard. ${ }^{9}$

These guarantees, in fact, are recognized only after the investigative service has sent to the parties its statement of objections, to which it is possible to reply within two months, with a possible extension. ${ }^{10}$ The same timeframe is also granted to the French Government, which is a party by law in all antitrust proceedings. Upon receipt of any observations, the investigative services generally prepare a Report of Inquiry - which is then notified to the parties, the Government Commissioner and the ministers concerned - to which it is possible to reply within two months. ${ }^{11}$

Moreover, as from the receipt of the statement of objections, the French system ensures the protection of the parties' procedural rights. In particular, from that moment, the correct application of the rules of procedure is ensured by a Conseiller Auditeur, ${ }^{12}$ who: i) suggests to the Rapporteur General the adoption of measures able to overcome detected problematic points; ${ }^{13}$ ii) collects written observations on procedural issues ${ }^{14}$ sent by the parties, as well as any replies from the Rapporteur General and/or other parties to the proceedings; ${ }^{15}$ iii) prepares an Investigation Report on the application of the rules of procedures, which is submitted to the President of the ADC at least ten days before the hearing, as well as communicated to the Rapporteur General and the other parties to the proceedings. ${ }^{16}$

The investigation stage ends with the written replies to the statement of objections (and, when applicable, to the Report of Inquiry), and a dossier is

8 See Paris Court of Appeal, 26 January 2012.

9 See ADC, Decision 14-D-19 of 18 December 2014, §§ 753-755

10 According to art. L463-2, the Rapporteur General - in exceptional circumstances - may extend the deadline for submitting the replies by one month. Such decision cannot be challenged before the Court.

11 However, according to art. L-463-3, the Rapporteur General may inform the parties - when sending the statement of objection - of his intention to send the case directly to the Board, without preparing the Report of Inquiry.

12 According to art. L-461-4 of the Code du Commerce, such role could be assigned to a judge or to someone who presents the same guarantees of independence, and the appointment is made by the Minister of Economy, after consultation with the Board. According to the annual Report for 2016, the Conseiller Auditeur intervened in eleven procedures: http://www. autoritedelaconcurrence.fr/doc/ra2016_conseiller_auditeur.pdf.

13 See Code du Commerce, art. R-461-9.

14 The complaint should concern facts that happened before the receipt of the invitation to the oral hearing before the Board: see Code du Commerce, art. R-461-9.

15 See Code du Commerce, artt. L-461-4 and R-461-9

16 See Code du Commerce, artt. L-461-4 and R-461-9. 
sent to the ADC Board ${ }^{17}$ for adjudication. In particular, the President assigns the case to one of the eight formations ${ }^{18}$ which - from that moment - will be in charge not only of the adoption of the final decision, but also of the resolution of any procedural issues brought to its attention by the Conseiller Auditeur.

With regard to the definition of procedural disputes, the Chairman examines the report prepared by the Conseiller Auditeur who - if the Chairman deems it appropriate - might be invited to take part in the oral hearing in order to illustrate his position. ${ }^{19}$ Therefore - although the Conseiller Auditeur plays a fundamental role in assisting in the correct execution of the procedure - the resolution of procedural issues is entrusted exclusively to the Board, which adopts the measures deemed most appropriate. A solution that - as highlighted by some authors (Lasserre, 2009, p. 10) - appears to be the most balanced, because the attribution of a decisional power directly to the Conseiller Auditeur would have implied the need to provide parties with an immediate jurisdictional remedy, with a clear impact on the on-going proceedings (in terms of their duration and increased complexity); attributing to the Board the decisional power even on procedural issues ensures, instead, the conclusion of the proceedings within reasonable time, while at the same time does not deprive parties of the possibility of challenging the conclusions reached by the Board on procedural aspects, given that the final decision can be challenged before the competent court also in relation to these aspects.

Subsequently, the Board examines the case during an in camera hearing, which the parties and the representative of the Government are allowed to attend. During the hearing, the Board may hear the parties requesting it, in addition to any other person whose hearing is considered useful for the

17 The Board is made up of a President, four Vice-Presidents and twelve non-permanent members. Pursuant to art. L461-1 of the Code du Commerce, the President is appointed by decree of the President of the Republic of France. By contrast all other members are appointed by the Minister of Economy and include: i) six judges (or former judges) of the Council of State, the Court of Cassation, the Court of Auditors or other administrative or ordinary judicial bodies; ii) five persons chosen for their competences in economics or in matters of competition and consumer protection; iii) five persons who work or have worked in the production, distribution, crafts, services and liberal professions sectors.

18 See art. 37 of the Rules of Procedure of the ADC (Decision of 30 March 2009, JORF No. 0080 of 4 April 2009). Nowadays it is possible to distinguish among: i) a 'plenary' format (composed of all 17 members of the ADC); ii) a 'permanent' one (composed of the President and four vice-presidents), two 'enlarged' ones (composed, respectively, of the President, four vice-presidents and 6 non-permanent members) and four 'simple' ones (presided over by one of the vice presidents and composed of five non-permanent members). See http://www. autoritedelaconcurrence.fr/doc/formations_college_nov17.pdf.

19 See Code du Commerce, art. R-461- 9 . 
purposes of the decision on the case. ${ }^{20}$ At the end of the hearing, the Board, if validly constituted, ${ }^{21}$ adopts a decision by a majority of the members present. ${ }^{22}$

The decisions taken can be appealed within a month before the Paris Court of Appeal, which may fully review the decision; ${ }^{23}$ the judgment could then be challenged before the Court of Cassation on points of law only. ${ }^{24}$

\section{The strengths and the weaknesses of the French system}

As it has been shown in the previous paragraph, the main feature of the French system is surely the clear separation existing between investigative and adjudicative functions, ${ }^{25}$ which ensures the impartiality of the Board from both a substantial and a procedural point of view, also allowing the Board to re-examine the case with a fresh pair of eyes (OECD, 2015 p. 11 and Lasserre, 2014, p. 3).

This feature has been praised by all French high Courts: the Constitutional Court, in the CanalPlus/TPS case, highlighted that the rules of procedure of the ADC were respectful of the principles of independence and impartiality,

20 See Code du Commerce, art. L-463-7. The same article also specifies that the Rapporteur General and the Government can submit written observations.

21 Art. 45 of the internal regulation of the ADC sets the minimum number of members for the plenary format to eight persons, and the minimum number of members for the permanent commission and the simple sections to three persons.

22 See Code du Commerce, art. L-461-3.

23 According to art. D-311-9 of the Code de l'Organisation Judiciaire, the Paris Court of Appeal has the exclusive competence to rule on appeals brought against ADC decisions concerning anticompetitive agreements and abuses of dominant position.

${ }^{24}$ See Code du Commerce, art. L 464-8.

25 This is the result of a long process, which begun in 1999 with the COB v Oury ruling (see Cour de cassation., Ad. Plen., 5 February 1999), where the French Supreme Court - examining the proceeding before the Commission des opérations de bourse ( $C O B$, the French Financial Markets Regulator) - observed that respecting the due process principle required a sufficient degree of separation between investigation and adjudication, and consequently the Rapporteur should have been excluded from the meetings of the Board: a conclusion that was reached also in relation to the proceedings before the competition authority, which shared with the COB both the nature of an independent authority and the decision-making process (see Cour de cassation, ch. Comm., 5 October 1999, SNC Campenon Bernard SGE). It is appropriate to point out that the presence of the Rapporteur in the decision-making stage was not the only provision likely to constitute a violation of the principle of due process: in fact, one year after the $C O B v$ Oury ruling, the Court of Appeal Paris heavily criticized the proceeding before the $C O B$, since the offices in charge of the investigation and decision-making activities were composed by the same people (see the Paris Court of Appeals, March 7 2000, KPMG, 1ere chambre, section H, 1999/15862). 
required of an independent administrative authority with sanctioning powers, and confirmed the absence of 'confusion between the investigating and the sanctioning function'; ${ }^{26}$ likewise, the Court of Cassation in the France Telecom case rejected a request for a constitutional preliminary ruling made by the applicant aimed at assessing the constitutional compatibility of the provisions on the 'functional separation' of the ADC; ${ }^{27}$ finally, the Council of State in the Colruyt case - by reviewing the internal decision-making process of the ADC - found the existence of an effective functional separation between investigation and adjudication and, thanks to that, excluded a violation of the principle of impartiality. ${ }^{28}$

Moreover, the current structure of the French system of antitrust enforcement seems also to be compliant with the impartiality principle enshrined in Article 6 of the European Convention of Human Rights (ECHR).

The ECHR requires, in fact, every court to offer sufficient guarantees to exclude any legitimate doubt in respect of its impartiality. ${ }^{29}$ Such requirement should, in principle, be met also by administrative authorities with fining powers, given that the European Court of Human Rights (hereinafter; ECtHR) - adopting a substantial approach ${ }^{30}$ - has put them on the same level as judicial courts. ${ }^{31}$ In examining the structure of administrative authorities, the ECtHR recognized that the presence within the same institution of an investigative and an adjudicative body is not per se incompatible with Article 6

26 See Conseil Constitutionnel, Decision n² 2012-280 QPC 12 October 2012.

27 See Cour de cassation, 30 November 2010. The Court observed that the request of the applicants 'ayant, notamment, pour objet et pour effet de parfaire la séparation des fonctions d'instruction et de décision au sein de l'Autorité de la concurrence, [...] ne présente pas de caractère sérieux au regard des exigences qui s'attachent aux dispositions, règles et principes de valeur constitutionnelle invoqués'.

28 See Council of State, 24 June 2013 n. 360949, Société Colruyt France et établissements FR Colruyt.

${ }^{29}$ See ECtHR, Micallef $v$ Malta, 15 October 2009, § 93.

30 See ECtHR, Engel and Others v. the Netherlands, 8 June 1976, § 82. In that case, the ECtHR elaborated on three criteria to assess whether a particular penalty is a criminal penalty for the purposes of art. 6 ECHR: the classification of the offence in national law, the nature of the offence, and the degree of severity of the penalty imposed on the offender. If one of the three criteria is met, the penalty is assessed as 'criminal' and the guarantees provided by art. 6 ECHR become applicable.

31 However, the ECtHR has clarified that the imposition of a fine by an administrative authority is not per se incompatible with the ECHR, in so far as this decision can be challenged before a court which offers all of the guarantees afforded by art. 6(1) ECHR and can exercise powers of full judicial review over the measure in question (see ECtHR, Menarini Diagnostics v Italy, 27 September 2011). 
ECHR, provided that a separation (or, at least, a functional segregation) between the two bodies is ensured. ${ }^{32}$

Such an internal separation (or segregation) is in effect present in the French system and makes the latter also a good source of inspiration for improving proceedings before the European Commission: although in fact both the French and the European systems of antitrust enforcement are 'monist' models, the latter does not seem to be compliant with Article 6 ECHR. In this regard, it is sufficient to recall that in the European Commission system, the separation between the adjudicative body (that is the College of Commissioners) and the investigative body (that is Commission services) ${ }^{33}$ is less evident, given that the latter drafts not only the statement of objections (which is, in effect, an act of the investigative body) but also the final decision (which is, instead, an act of the adjudicative body) (Temple Lang, 2015 p. 195). A circumstance that - as highlighted by the European Commission already forty years ago - has brought the 'feeling of insatisfaction with the fact that the Commission holds concurrently powers of investigation, examination and decision' (European Commission, 1979 § 16).

Whilst the adjustments made to the French system allow it to comply with the impartiality principle, they also expose it to some criticism. In fact, unlike other monist systems - where investigative bodies tend to follow (more or less cogent) instructions coming from the Board (which therefore exercises control over the case all along the proceeding) - the functional segregation that characterizes the French system precludes any form of control of the Board over the work of the investigating team. However, the risk exists that the work of the adjudicative body would be reduced in the majority of cases to an uncritical approval of the case team's position. In fact, due to the structure of the proceeding, the case is examined by the Board for the first time at the end of the investigative stage and so - in order to allow the Board to adopt an informed decision - it would be necessary to provide the latter with enough time to review the entire case-file. However, such operation would take a lot of time, and would hardly be possible in the timeframe of the proceedings: a circumstance that suggests the absence of a critical review on the conclusions reached by the investigating team.

Moreover, there is the risk that investigators send firms statements of objections with charges that go far beyond what would be reasonable and justified. This is because investigators do not know the opinion of the Board

32 See ECtHR, Dubus v France, 11 June 2009, $\$$ 57-60, where it was excluded that the French Commission bancaire was impartial in the meaning of art. 6 ECHR.

33 In this regard, see case C-209/78, Van Landewyck v Commission, 29 October $1980 § 81$, where the ECJ held that the European Commission 'cannot, however, be classed as a tribunal within the meaning of Article 6 of the European Convention for the Protection of Human Rights'. 
on the case and so - in order to avoid having their case sent back by the Board - tend to include in the statement of objections any potential violations of the law (even those that are not well-founded) leaving it then to the Board to take the decision on which charges to found the case. This is an approach that aggravates the parties' defences, obliging them to reply even to those charges which are considered clearly unfounded (Jenny, 2016, pp. 25-26).

Beside the adjustments adopted to ensure the impartiality of the proceeding - and which, as we have seen, have both advantages and disadvantages - the French system presents other strengths and weaknesses also.

The French model, in particular, has the advantage of providing parties with two moments to respond in writing to the allegations of the investigative service (that is in response to the statement of objection and to the Inquiry Report). This surely represents a strengthening of the adversarial principle, which - according to the ECtHR - makes it necessary to give each party the opportunity to have knowledge of and comment on the observations filed and the evidence adduced by the other party, in order to be able to influence the decision of the judge. ${ }^{34}$

Moreover, such a model offers also to the parties an oral hearing before the Board when they can reply orally to the investigative services. Even under this profile, such a system appears in line with the case law of the ECtHR that requires giving the parties the opportunity to try to persuade the adjudicating body during a dedicated hearing. ${ }^{35}$ Once again, such system could be a source of inspiration for the European one, as in the latter the hearing takes place before an official (the hearing officer), with the consequence that Commissioners - in adopting their decision - have to reconstruct the hearing relying only on 'second-hand' information: the intermediate report of the hearing officer ${ }^{36}$ and the (merely potential) report made by EU Commission officials which assisted the hearing. ${ }^{37}$

Despite these objective points of strengths, the system appears, in other ways, unable to ensure the parties' right of defence.

In fact, the first part of the investigative stage (that is before the notification of the statement of objections) is too unbalanced in favour of the investigative service, with no instruments to protect the parties against potential abuses of the investigating team. Parties, in particular, do not have the right to be

${ }^{34}$ See ECtHR, Rowe e Davis v United Kingdom, 16 February 2000, § 60.

35 See ex multis, ECtHR, Martinie v France, 12 April 2006, § 40.

36 See Decision of the President of the European Commission no. 2011/695/EU of 13 October 2011 on the function and terms of reference of the hearing officer in certain competition proceedings, OJ L 275/2011, art. 14.

37 See Commission notice on best practices for the conduct of proceedings concerning Articles 101 and 102 TFEU, OJ C 308/211, § 108. 
heard by the investigative service and cannot have access to the documents of the proceeding, even when the Rapporteur wants to hear the party.. This represents not only a clear breach of the adversarial principle, which implies and incorporates the right of access to the documents relevant for the case, ${ }^{38}$ but also of the equality of arms principle, given that - denying access to the file before the hearing - the investigative service is placed in a position of substantial advantage vis-à-vis its opponent. ${ }^{39}$

The lack of balance in the proceedings in favour of the investigative services is confirmed by the legislative choice to attribute to the Conseiller Auditeur the competence of ensuring the correct application of the rules of procedure starting from the moment of the notification of the statement of objections ${ }^{40}$ (see Article R461-9). A provision that clearly leaves the parties without protection for the entire first stage of the proceedings appears to be in breach of the parties' rights of defence.

In the light of the above, it appears appropriate to extend the protection granted to the parties in the adjudicative stage to also cover the investigative stage of the proceedings. This would allow parties to invoke, starting from the time of the actual opening of the proceeding, all those procedural rights (such as the right to access to the file and to be heard) that at the present can be invoked only after the notification of the statement of objections, thus ensuring compliance with Article 6 ECHR.

\section{Conclusion}

The analysis carried out in this paper made it possible to reflect on a new potential structure for enforcement agencies, characterized by the functional segregation between investigative and adjudicative bodies, in line with Article 6 ECHR. However, while such model offers, on one side, the advantage of ensuring the autonomy of the adjudicative body from the investigative one, ${ }^{41}$ on the other side it does not necessarily ensure the adoption of an impartial decision, especially if the functional segregation is not accompanied by other adjustments that enable the Board to re-examine the case effectively.

38 The strict relation between the adversarial principle and the right to be heard has been acknowledged also by the ECJ, joined cases C-56/64 e 58/64, Consten and Grundig, 13 July 1966.

39 See ECtHR, Delcourt v Belgium, 17 January 1970, § 34.

40 See Code du Commerce, art. R-461-9.

41 On this point, see the opinion expressed by Moses $\mathrm{J}$ and recalled by the ECtHR, Tsfayo $v$ United Kingdom, 14 November 2006, § 33, whereby 'One of the essential problems which flows from the connection between a tribunal determining facts and a party to the dispute is that the extent to which a judgment of fact may be infected cannot easily be, if at all, discerned'. 
Moreover - and more in general - the study of the French system represents also an occasion to evaluate whether a model where the investigative body is separated from the adjudicative one is preferable to one where the two bodies are instead more integrated: although in fact the impartiality principle - as interpreted by ECtHR - requires such a separation, the absence of coordination between the two bodies could have a negative impact on respecting the defence rights of the parties.

In conclusion, the analysis of the French system and the brief considerations on its main strengths and weaknesses can offer some food for thought to the debate on the design of competition authorities, thus adding a new 'piece' to a very complex puzzle.

\section{Literature}

European Commission (1979). XI Report on Competition Policy, Brussels and Luxembourg: European Commisison, retreived from: https://publications.europa.eu/en/publicationdetail/-/publication/26e12860-4710-46be-bcfc-60582d4e51b2/language-en (20.06.2018).

Jenny, F. (2016). The institutional design of Competition Authorities: Debates and Trends. In F. Jenny, Y. Katsoulacos (eds.), Competition Law Enforcement in the BRICS and in Developing Countries. International Law and Economics (pp. 1-58). Switzerland: Springer, http://dx.doi.org/10.1007/978-3-319-30948-4.

Lasserre, B. (2008). La transformation du Conseil de la concurrence en Autorité de la concurrence, clé de voûte d'une régulation de la concurrence moderne, juste et efficace (pp. 1-28). Retrieved from: http://www.autoritedelaconcurrence.fr/doc/du_conseil_a_1_ autorite_jan09_bl_journal_societes.pdf (20.06.2018).

Lasserre, B. (2009). La nouvelle Autorité de la concurrence. Concurrences 1, 1-12. Retrieved from: http://www.autoritedelaconcurrence.fr/doc/concurrences_1_2009_itv_ bl.pdf (20.06.2018).

Lasserre, B. (2014). A fully-functioning administrative competition authority: the French example, speech delivered at the Competition Conference in Wien. Retrieved from: https://www.bwb.gv.at/fileadmin/user_upload/Bilder/Veranstaltungen/121_10Bruno_ Lasserre_Speaking_Notes.pdf (20.06.2018).

OECD (2015). Roundtable on changes in institutional design of competition authorities - contributon by the French Autorité de la Concurrence for Item VIII of the 122nd meeting of the OECD Competition Committee, DAF/COMP/WD(2014)104. Retrieved from: http://www.oecd.org/officialdocuments/publicdisplaydocumentpdf/?cote $=\mathrm{DAF} /$ COMP/WD(2014)104\&doclanguage $=$ en (20.06.2018).

Temple Lang, J. (2011), Three possibilities for reform of the procedure of the European Commission in Competition cases under Regultion 1/2003. Ceps special report, 194-230. Retrieved from: https:/www.ceps.eu/publications/three-possibilities-reform-procedureeuropean-commission-competition-cases-under (20.06.2018). 